\title{
The possibilities of the environmental use of bottom sediments from the silted inlet zone of the Rożnów Reservoir
}

\author{
Marek Tarnawski ${ }^{1}$, Agnieszka Baran ${ }^{2}$, Tomasz Koniarz ${ }^{1}$, Maciej Wyrębek ${ }^{1}$, \\ Jerzy Grela ${ }^{3}$, Monika Piszczek ${ }^{3}$, Agnieszka Koroluk ${ }^{3}$ \\ ${ }^{1}$ University of Agriculture in Krakow, Faculty of Environmental Engineering and Land Surveying, Department of Hydraulic \\ Engineering and Geotechnics; al. A. Mickiewicza 24/28, 30-059 Krakow, Poland; e-mail: marek.tarnawski@ur.krakow.pl \\ ${ }^{2}$ University of Agriculture in Krakow, Faculty of Agriculture and Economics, Department of Agricultural and Environmental \\ Chemistry; al. A. Mickiewicza 21,31-120 Krakow, Poland; e-mail: Agnieszka.Baran@ur.krakow.pl \\ ${ }^{3} M G G P$ S.A.; Tarnów, Poland; e-mail:mggp@mggp.com.pl
}

(C) 2017 Authors. This is an open access publication, which can be used, distributed and reproduced in any medium according to the Creative Commons CC-BY 4.0 License requiring that the original work has been properly cited.

Received: 11 December 2017; accepted: 19 January 2018

\begin{abstract}
The aim of the study was to assess the properties of bottom sediments from the inlet zone of the Rożnów Reservoir (South Poland) and to analyse the potential possibilities to use them for environmental purposes. The inlet zone of the reservoir is particularly intensely shallowed by means of the silts of the Dunajec River. A total of 20 samples were collected from the designated cross-sections. In air-dry samples of the sediments, granulometric composition, $\mathrm{pH}$ electrolytic conductivity (EC), sorption properties, organic carbon carbonates and macroelements content were determined. Bottom sediments from the Rożnów Reservoir indicate a great potential possibility to use them for environmental purposes (agriculture, reclamation). However, in order to fully evaluate the possibility of bottom sediment management, it is necessary to carry out an analysis of the ecological risk related to the content of heavy metals, PAHs, PCBs and to evaluate their eco-toxicity. Moreover, the main barriers to the environmental application of bottom sediments are a lack of appropriate legislation.
\end{abstract}

Keywords: bottom sediment, environmental purposes, chemical properties

\section{INTRODUCTION}

Sediments formed at the bottom of reservoirs are an important part of water ecosystems; as a consequence, the need to treat the phenomenon of reservoir silting arises not only in the technical (functional) aspect, but also with regard to analysing its effects in geochemical, quantitative and qualitative terms, especially in relation to reservoir sediments potentially intended for modernisation (Fonseca et al. 1998, Szalińska 2011, Walter et al. 2012). The dredging of water reservoirs is a commonly used procedure to maintain them in the proper condition needed to meet their economic functions. As the phenomenon of silting and shallowing of water reservoirs is inevitable, it seems rational to attempt to use the parts of sediments which do not contain harmful pollutants, and the content of macronutrients can influence the quality of the plants cultivated on the soil with the addition of bottom sediment (Jasiewicz et al. 2011). Significant barriers limiting land-based sediment disposal include difficulties in their obtainment, significant hydration, pollution by inorganic and organic compounds as well as the formation of leachates that may adversely affect soil 
and groundwaters (Stephens et al. 2001, Piou et al. 2009, Ciesielczuk et al. 2011, Baran \& Tarnawski 2012). Not without significance are also unclear legal aspects related to sediment quality assessment and classification (Ciesielczuk et al. 2011, Maj \& Koszelnik 2016). Moreover, studies and experiments to date have shown that there are opportunities for the environmental development of bottom sediments (Fonseca et al. 2003, Perrodin et al. 2006, Karanam et al. 2008, Sheenen et al. 2010, Baran et al. 2012, 2015, Mamindy-Pajany et al. 2011, Terziyski et al. 2014, Wyrwicka et al. 2014, Tarnawski et al. 2015, Mattei et al. 2016). There are also indications that sediments rich in nutrients (NPK), organic carbon and microbial activity can be used as fertiliser substitutes for crop production (Canet et al. 2003, Ebbs et al. 2006, Karanam et al. 2008, Baran et al. 2011, Jasiewicz et al. 2010, 2011, Baran et al. 2016). In turn, other authors show that sediments meeting the geotechnical criteria can be used in road construction, hydro-technical and as insulation layers of landfills (Becquart et al. 2008, Siham et al. 2008, Zentar et al. 2008, Koś \& Zawisza 2012, Zawisza et al. 2014). However, before deciding if the dredged material is acceptable for a beneficial use, it is necessary to evaluate the physical and chemical properties of the material.

The aim of the study was to assess the physical and chemical properties of bottom sediments collected from the backwater zone of the Rożnów Reservoir and to analyse the potential possibilities of utilising them for environmental purposes.

\section{MATERIALS AND METHODS}

\section{Study area and sampling}

Put into operation in 1942, the Rożnów Reservoir is one of the largest reservoirs located in southern Poland. It is the third reservoir on the Dunajec River, after the Czorsztyn and the Sromowce reservoirs. The inlet zone of the reservoir is particularly intensely shallowed through the silts of the Dunajec. This zone was included in studies of the properties of sediments deposited there. A total of 20 core samples were collected from the designated cross-sections (Fig. 1). The sediment was sampled from under the water mirror using Beeker- and Instorf-type probes. During the tests, cores at the depth of 3-5 m below the bottom were created from the collected samples.
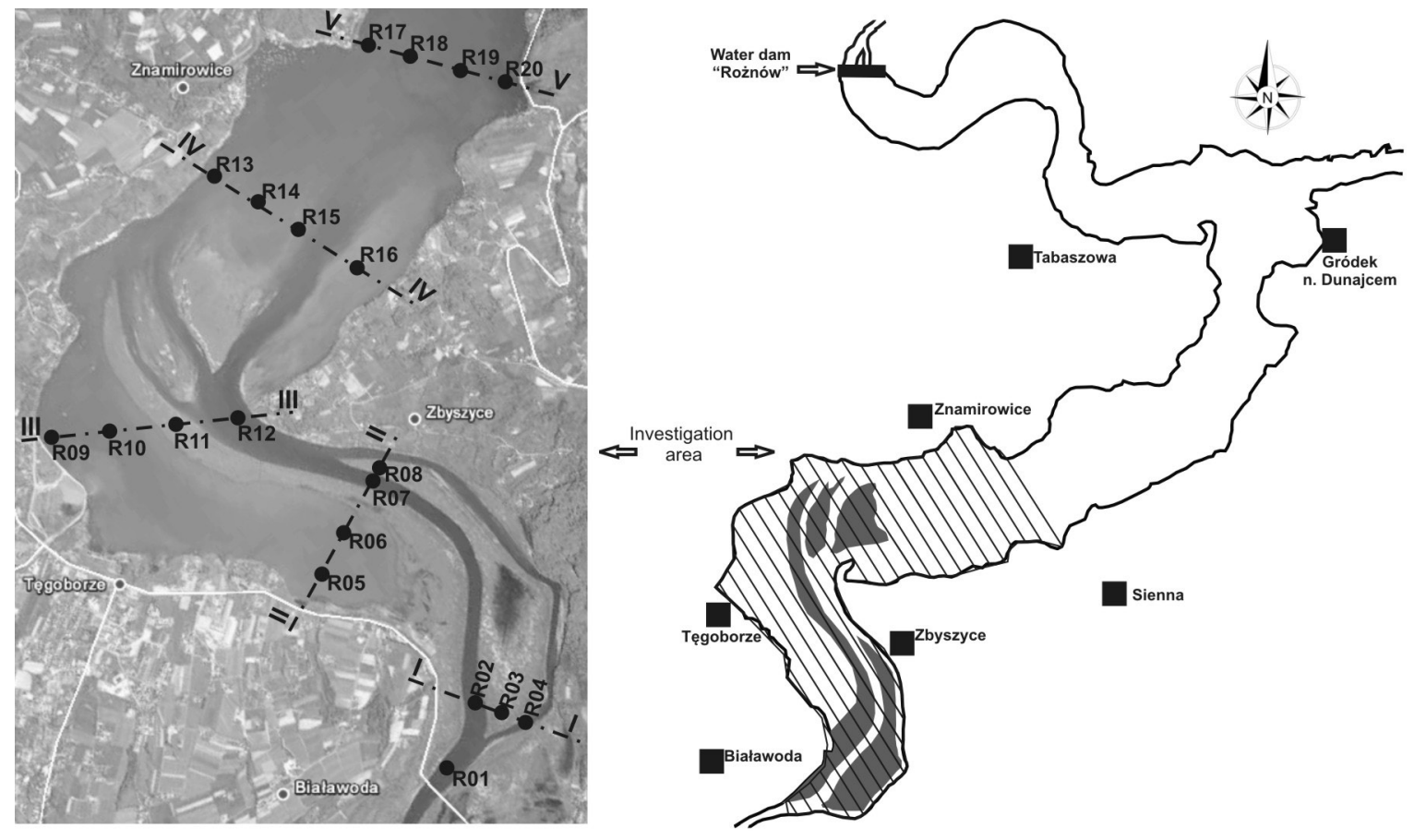

Fig. 1. The area of the Rożnów Reservoir included in the studies of bottom sediments 
After extraction, the material was homogenised and the sample preparation procedure was made in accordance with the Ordinance of the Minister of the Environment of the $11^{\text {th }}$ May 2015 on the recovery of waste outside installations and equipment (Rozporządzenie 2015).

\section{Chemical analysis}

In air-dry samples of the sediments, granulometric composition with the use of the Casagrande method in Prószyński modification, $\mathrm{pH}$ in $1 \mathrm{~mol} \mathrm{KCl} \cdot \mathrm{dm}^{-3}$, electrolytic conductivity (EC) with the use of the potentiometric method, carbonate content with the use of the Scheibler method, organic carbon content, sorption properties (hydrolytic acidity with the use of the Kappen method, the content of exchangeable alkaline cations) and the total content of macroelements $(\mathrm{Ca}$, $\mathrm{Mg}, \mathrm{Na}, \mathrm{K}, \mathrm{P}, \mathrm{N}, \mathrm{S}$ ), were determined.

The content of organic carbon, nitrogen and sulphur were determined using the Vario Max Cube analyser, while the content of the remaining elements was determined using the inductively coupled plasma optical emission spectrophotometer (ICP-OES) Optima 7300 DV model by Perkin-Elmer. Total macroelement $(\mathrm{Ca}$, $\mathrm{Mg}, \mathrm{Na}, \mathrm{K}, \mathrm{P}$ ) content in the sediments was assessed after hot digestion in a mixture of $\mathrm{HNO}_{3}$ and $\mathrm{HClO}_{3}(3: 2 \mathrm{v} / \mathrm{v})$ acids (suprapure, MERCK). During the chemical analyses, each sample of the bottom sediment was analysed in two repetitions. Statistical calculations included the following basic parameters: average, standard deviation, minimum, maximum, coefficient of variation. The statistical analysis was performed using the Statistica 12 software.

\section{RESULTS}

\section{The basic properties of bottom sediments}

The analysis of the granulometric composition showed the advantage of the presence of low- and medium-cohesive soils, i.e. dusty clays, clays, sand dusts and clay sand. Comparing the percentage content of individual fractions, the dominance of dusty and loam fraction in the bottom sediments of the backwater zone of the Rożnów Reservoir (Fig. 2) was determined.

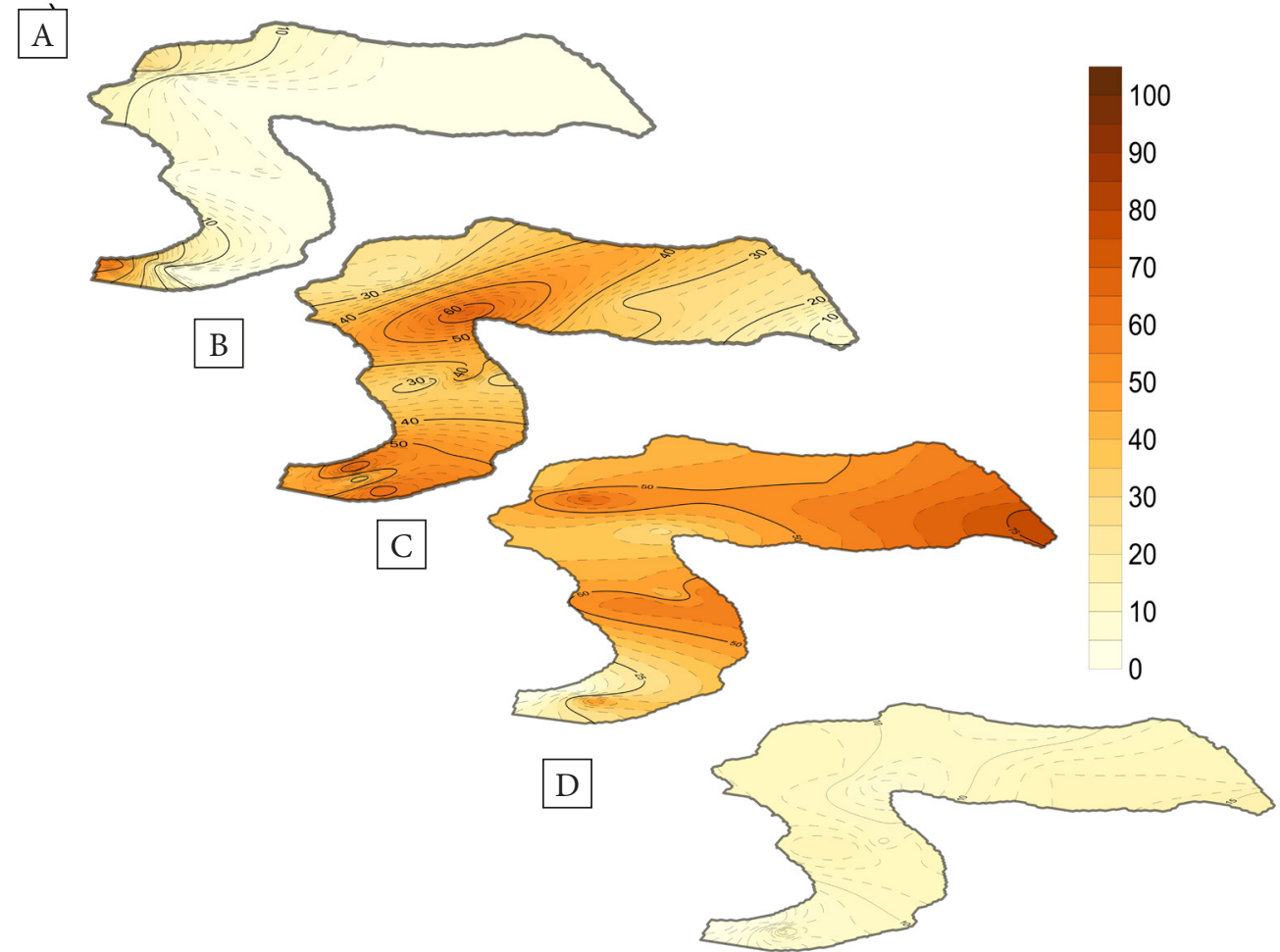

Fig. 2. Spatial distribution of the granulometric properties of bottom sediments of the Rożnów Reservoir inlet zone: A) gravel and pebble fraction; B) sandy fraction; C) dusty fraction; D) loam fraction 
In general, small differences in the physicochemical and chemical properties of the bottom sediments of the Rożnów Reservoir inlet zone were determined. Only the overall sulphur content was significantly different, and the coefficient of variation for this parameter amounted to $74 \%$ (Tab. 1). The sediments were neutral and alkaline, and their $\mathrm{pH}$ ranged from 7.07 to 7.41 . The tested sediments were also rich in mineral salts, as evidenced by the high electrolytic conductivity values ranging from 0.16 to $0.59 \mathrm{mS} \cdot \mathrm{cm}^{-3}$. The content of carbonates in the sediments ranged from 1.60 to $5.68 \%$ (Tab. 1, Fig. 3). The highest content of carbonates and the highest EC value were found in the sediments collected in cross-section $\mathrm{V}$ and the lowest in cross-section I.

\section{Table 1}

Basic statistics of the physicochemical properties of bottom sediments in the inlet zone

\begin{tabular}{|c|c|c|c|c|c|c|c|c|}
\hline Parameters & $\mathrm{pH}$ & EC & $\mathrm{CaCO}_{3}$ & Hh & $S$ & $\mathrm{~T}$ & \multirow{2}{*}{$\frac{\text { C-organic }}{\left[\mathrm{g} \cdot \mathrm{kg}^{-1} \text { d.m. }\right]}$} & \multirow{2}{*}{$\mathrm{C}: \mathrm{N}$} \\
\hline & {$[\mathrm{KCl}]$} & {$\left[\mathrm{mS} / \mathrm{m}^{3}\right]$} & [\%] & \multicolumn{3}{|c|}{$[\mathrm{mmol}(+) / 100 \mathrm{~g} \mathrm{~d} . \mathrm{m}]}$. & & \\
\hline Mean & 7.21 & 0.39 & 4.51 & 1.74 & 45.44 & 47.18 & 18.75 & 17 \\
\hline SD & 0.08 & 0.11 & 1.06 & 0.29 & 13.24 & 13.34 & 6.32 & 6 \\
\hline Min. & 7.07 & 0.16 & 1.60 & 0.90 & 13.90 & 14.80 & 5.34 & 13 \\
\hline Max. & 7.41 & 0.59 & 5.68 & 2.20 & 64.25 & 65.85 & 26.28 & 42 \\
\hline CV\% & 1 & 29 & 23 & 17 & 29 & 28 & 34 & 35 \\
\hline
\end{tabular}

Explanations: EC - electrolytic conductivity, Hh - hydrolytic acidity, S - sum of bases, T - sorption capacity.
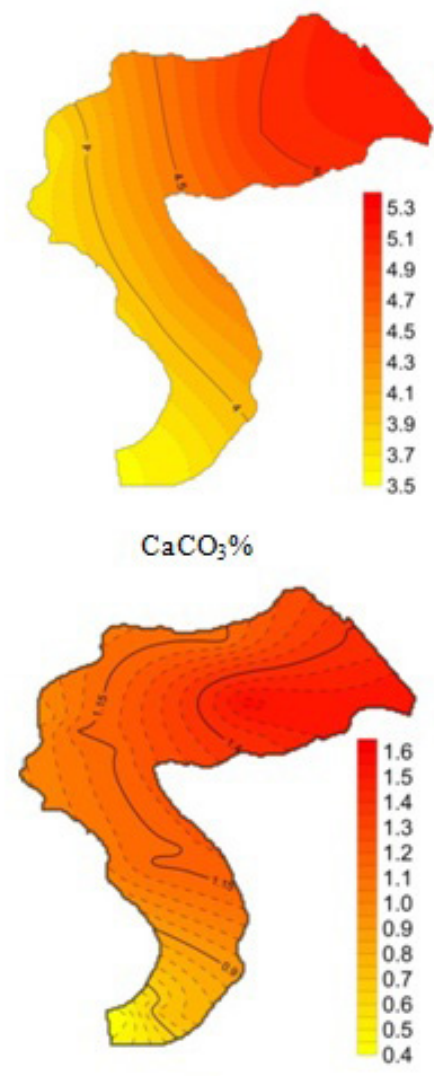

$\mathrm{Ng} \cdot \mathrm{kg}^{-1}$

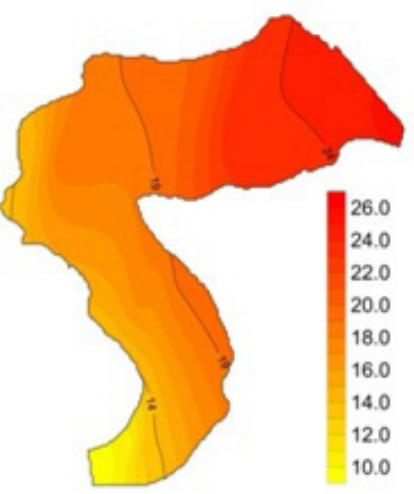

C organic $\mathrm{g} \cdot \mathrm{kg}^{-1}$

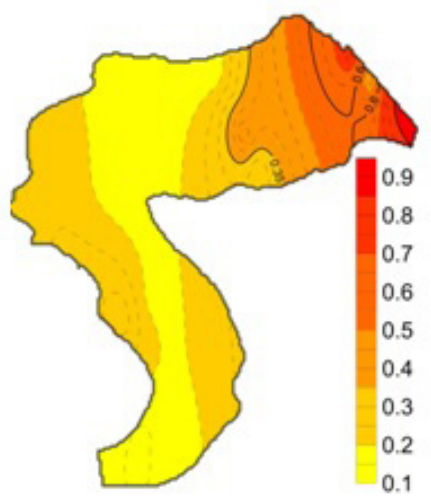

$\mathrm{Sg} \cdot \mathrm{kg}^{-1}$

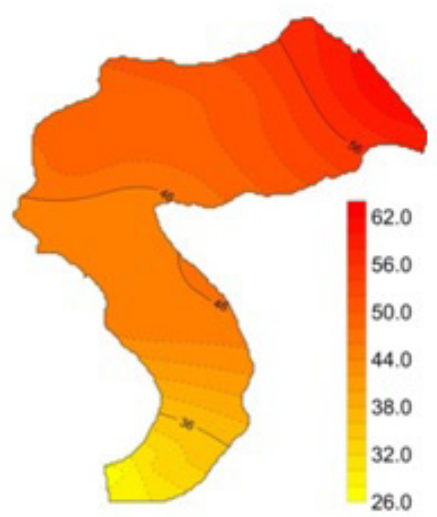

$\mathrm{T} \mathrm{mmol}(+) \cdot 100 \mathrm{~g}^{-1}$

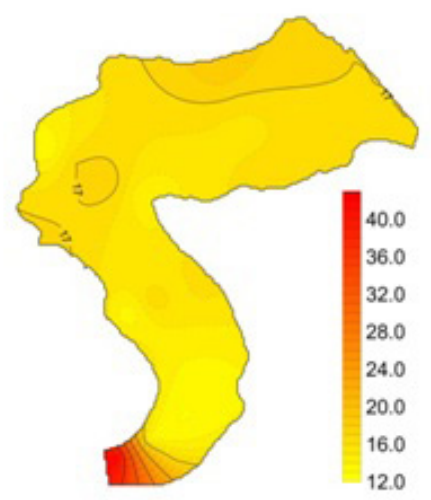

$\mathrm{C}: \mathrm{N}$

Fig. 3. Spatial distribution of selected physicochemical and chemical properties of the bottom sediments of the Rożnów Reservoir inlet zone 
In the studies conducted by Komornicki et al. (2011), the pH of the Rożnów Reservoir sediments was in the range of 7.5 to 8.1 , while the carbonate content was between $2.27-6.79 \%$. These values are close to those presented in this paper. A neutral and alkaline reaction is a positive feature of the tested sediments, as in such conditions the tested sediments can be used to improve the reaction of acid soils and thus improve the productivity of these soils. In addition, the reaction has the greatest effect on the mobility of heavy metals: the lower the $\mathrm{pH}$, the greater the solubility of the individual metals. Due to the alkaline and neutral reaction of the tested sediments, when applied to soils contaminated with heavy metals, they may affect the solubility and bioavailability of toxic metals (Baran et al. 2010, 2011). In alkaline bottom sediments, calcium carbonate decides on the buffering capacity of the sediment in terms of $\mathrm{pH}$ changes. It is important that, with the alkaline reaction resulting from the presence of carbonates, the mobility of pollutants in the environment is limited (Al-Mur et al. 2017). In the environmental use of bottom sediments to improve soil properties, calcium carbonate contained in bottom sediments will constitute a backup form of calcium which is significant when taking high leaching of this element and its significant removal with plant yield into account. Calcium carbonate impacts the soil in structure-forming terms and favours the formation of persistent organic matter and the accumulation of humus.

\section{Sorptive properties of bottom sediments}

Sorption capacity is the sum of all alkaline cations $\left(\mathrm{Ca}^{2+}, \mathrm{Mg}^{2+}, \mathrm{K}^{+}\right.$and $\left.\mathrm{Na}^{+}\right)$and acid cations $\left(\mathrm{H}^{+}, \mathrm{Al}^{3+}\right)$ absorbed by the solid phase of the sediment. This parameter is most influenced by the content of colloidal loam and organic matter. In sediment samples, the value of $\mathrm{Hh}$ ranged from 0.9 to $2.2 \mathrm{mmol}(+) \cdot 100 \mathrm{~g}^{-1}$ d.m., while $\mathrm{S}$ from 13.90 to $-64.25 \mathrm{mmol}(+) \cdot 100 \mathrm{~g}^{-1}$ d.m. (Tab. 1). The sorption capacity $(\mathrm{T})$ of the sediments ranged from 14.80 to $65.85 \mathrm{mmol}(+) \cdot 100 \mathrm{~g}^{-1}$ d.m., with the highest sorption capacity value determined in the sediments collected in cross-section $\mathrm{V}$ and the lowest value in cross-section I (Tab. 1, Fig. 3). Bottom sediments were generally characterised by a high ( $75 \%$ of samples), average (20\%) and low
(5\%) class of sorption capacity. Moreover, in the sorption complex of the analysed sediments, the dominance of alkaline cations (average $\mathrm{V}=96 \%$ ) was observed, and the content of exchangeable alkaline cations in sediments formed the following sequence: $\mathrm{Ca}^{2+}>\mathrm{Mg}^{2+}>\mathrm{K}^{+}>\mathrm{Na}^{+}$. In the studies conducted by Komornicki et al. (2011), a low Hh value $\left(0.26-0.77 \mathrm{mmol} \cdot 100 \mathrm{~g}^{-1}\right)$ and a high $\mathrm{S}$ value (6.5-31.4 mmol.100 $\left.\mathrm{g}^{-1}\right)$ were also determined in the bottom sediments of the Rożnów Reservoir, while the dominance of $\mathrm{Ca}^{2+}$ ions was determined in the sorption complex. Sorption capacity is an important parameter from the point of view of sediment quality, since it is essential for limiting the migration and bioavailability of pollutants, and in the case of an environmental use of sediments, with high sorption capacity, the ingredients supplied with fertilisers/fertilising materials will not be washed deep into the soil profile and into groundwater, but will be activated from the sorption complex during the plant development period. In addition, a high degree of saturation with alkaline cations of the sorption complex of the tested sediments has an undeniably positive influence on their physicochemical properties (reaction, water-air ratio, structure) and especially their buffer properties. Buffer properties of sediments play a very important role in the sorption and release of pollutants.

\section{Content of $\mathrm{C}, \mathrm{N}, \mathrm{S}$ in bottom sediments}

In water reservoirs, the sources of organic matter accumulated in different forms in bottom sediments are the remains of organisms and the products of their decomposition. The content and quality of organic matter is an important feature of bottom sediments from the point of view of the physicochemical conditions prevailing at the bottom of the reservoir as well as one of the basic factors determining the fertility of bottom sediments. Organic matter has a variety of indirect and direct functions in the formation of physical, physicochemical and biochemical properties of sediments. It affects the rheological properties of the particles and, consequently, the sedimentation and consolidation processes. The processes of organic matter mineralisation are responsible, to a large extent, for releasing nitrogen and phosphorus compounds into the water depth as 
well as releasing toxic compounds, such as ammonia, heavy metals and various organic pollutants to aquatic organisms. The main component of organic matter is organic carbon. In the analysed bottom sediment samples, a low organic carbon content was determined, ranging from 5.34 to $26.28 \mathrm{~g} \cdot \mathrm{kg}^{-1}$ d.m. (Tab. 1). In comparison, bottom sediments of the Chańcza Reservoir contained on average $35.4 \mathrm{~g}$, the Besko Reservoir $18.2 \mathrm{~g}$, the Zesławice Reservoir $15.8 \mathrm{~g}$ and the Chechło Reservoir from 8.2 to $245 \mathrm{~g}$, the Rzeszów Reservoir $23.5 \mathrm{~g}$, the Ożanna Reservoir $31.3 \mathrm{~g} \mathrm{C} \cdot \mathrm{kg}^{-1} \mathrm{~d}$.m. (Baran et. al 2011, Tarnawski et al. 2012, Zawisza et al. 2014, Koniarz et al. 2015). The tested sediments were also characterised by a relatively low content of nitrogen $\left(0.16-1.77 \mathrm{~g} \mathrm{~N} \cdot \mathrm{kg}^{-1} \mathrm{~d} . \mathrm{m}\right)$ as well as sulphur (0.13-0.88 g S.kg-1 d.m.) (Tab. 2, Fig. 3). Similarly to the abovementioned parameters, the content of $\mathrm{C}, \mathrm{N}, \mathrm{S}$ in bottom sediments was the highest in cross-section $\mathrm{V}$ and IV and the lowest in cross-section I (Figs. 1, 3). In comparison, the sediments of the Dobczycki Reservoir contained from 2.06 to $2.44 \mathrm{~g} \mathrm{~N} \cdot \mathrm{kg}^{-1}$; the Zesławice Reservoir from 1.02 to $1.08 \mathrm{~g}$ (Jasiewicz \& Baran 2006); the Chańcza Reservoir from 0.45 to $4.93 \mathrm{~g}$ (Tarnawski et. al. 2012); the Chechło Reservoir from 0.23 to 8.38 (Zawisza et al. 2014); the sediments of the lakes in the Wielkopolski National Park (WPN) from 1.5 to $19.5 \mathrm{~g}$, Lake Długie Wielkie from 2.2 to $14.4 \mathrm{~g}$ (Trojanowska \& Antonowicz 2005). In the studies conducted by other authors, the content of sulphur in the bottom sediments of the Bielszowicki Stream (an area of anthropogenic activity) amounted to 4.9 to $8.8 \mathrm{~g} \cdot \mathrm{kg}^{-1} \mathrm{~d} . \mathrm{m}$. (Działoszyńska-Wawrzkiewicz et al. 2015) and in the sediments of the Mielnica watercourse 0.055 to $0.16 \mathrm{~g} \cdot \mathrm{kg}^{-1} \mathrm{~d}$.m. (Linczar et al. 2005). In the studies conducted by Niemiec (2007) concerning the environmental management of the bottom sediments of the Rożnów Reservoir collected from the lagoon in Znamirowice, the content of organic carbon amounted to $3.65 \mathrm{~g} \mathrm{C}$ and nitrogen $1.19 \mathrm{~g} \mathrm{~N} \cdot \mathrm{kg}^{-1} \mathrm{~d} . \mathrm{m}$. In turn, in the research conducted by Komornicki et al. (2011), the content of organic carbon in bottom sediments of the Rożnów Reservoir ranged from 4.30 to $22.3 \mathrm{~g} \cdot \mathrm{kg}^{-1} \mathrm{~d}$.m., and nitrogen content ranged from 0.38 to $1.93 \mathrm{~g} \cdot \mathrm{kg}^{-1} \mathrm{~d}$.m. An important parameter in the aquatic and soil environment is the ratio of carbon and nitrogen $(\mathrm{C}: \mathrm{N})$. This ratio determines the rate of the mineralisation of organic matter; the lower the ratio, the higher the degree of mineralisation. In addition, the C:N ratio in sediments may be an indicator of temporal changes in organic matter cycles in aqueous systems. In the analysed sediments of the Rożnów Reservoir, the ratio of carbon content to nitrogen content C:N amounted to 17 on average and fluctuated from 13 to 42 (Tab. 1, Fig. 3). In aqueous systems, low values in the C:N ratio $(<10)$ indicate that the main source of organic matter is phytoplankton, whereas high values of more than 20 are determined for organic matter derived from the transformation of macrophytes and higher plants rich in cellulose (Meyers 1997). The optimal C:N ratio for microorganisms amounts to 17 and its low values cause the release of nitrogen into the water during the process of the microbiological decomposition of the organic matter, leading to the eutrophication of the reservoir (Sobczyński \& Siepak 2001). In most of the sediment samples (55\% of samples) among the tested bottom sediments, the C:N ratio amounted to the optimal value of 17 or close to the optimal value, which also suggests that the main source of organic matter in bottom sediments is the inlet with the waters supplying the reservoir with humus substances of land origin. In comparison, in the research conducted by other authors, the C:N content ratio ranged from 12 to 35 in the Krempna Reservoir; from 13 to 15 in the Zesławice Reservoir (Jasiewicz \& Baran 2006), from 2 to 27 in the sediments of Lake Długie Wielkie (Trojanowska \& Antonowicz 2005), from 1.4 to 213 in the sediments of the Chechło Reservoir (Zawisza et al. 2014), 13 in the sediments of the Besko Reservoir (Baran et al. 2011), and from 7 to 18 in the sediments of the Chańcza Reservoir (Tarnawski et al. 2012).

\section{Content of macroelements (Ca, K, P, Mg, Na) in bottom sediments}

The total content of macronutrients in bottom sediments is shown in Table 2 and Figure 4. The content of macro-elements in sediments ranged as follows: $\mathrm{K}$ - from 0.5 to $6.27 \mathrm{~g}$; $\mathrm{Ca}$ - from 6.28 to $29.88 \mathrm{~g} ; \mathrm{Na}$ - from 0.04 to $0.33 \mathrm{~g}$; $\mathrm{Mg}$ - from 2.48 to $7.58 \mathrm{~g}$ and $\mathrm{P}-$ from 1.8 to $6.42 \mathrm{~g} \cdot \mathrm{kg}^{-1} \mathrm{~d} . \mathrm{m}$.; in quantitative terms, the analysed elements in 
bottom sediments formed the following sequence: $\mathrm{Ca}>\mathrm{Mg}>\mathrm{P}>\mathrm{K}>\mathrm{Na}$; whereas in terms of differentiation, the sequence was as follows, respectively: $\mathrm{K}>\mathrm{Na}>\mathrm{Ca}>\mathrm{P}>\mathrm{Mg}$. A low degree of variation in the content of the analysed macronutrients was determined, while the value of the variation coefficient ranged from 23 to $41 \%$ (Tab. 2). The highest (maximum) content of $\mathrm{K}, \mathrm{Ca}, \mathrm{Na}$ and $\mathrm{Mg}$ was found in samples of sediments collected at point 20 (cross-section V) and $\mathrm{P}$ in sample 15 (cross-section IV). The average content of macro-elements in sediments in the designated cross-sections constituted the following sequence (in descending order): Ca, Na: V > IV > II > III > I; Mg, K: V > IV, II $>$ III $>$ I and P: V $>$ IV $>$ III, II $>$ I (Figs. 1, 3). In comparison, the content of macro-elements in the bottom sediments of the Krempna and Zesławice reservoirs ranged from 3.16 to $31,51 \mathrm{~g} \mathrm{Ca}$; from 1.31 to $4.58 \mathrm{~g} \mathrm{Mg}$; from 1.23 to $5.62 \mathrm{~g} \mathrm{~K}$ and from 0.14 to $0.31 \mathrm{~g} \mathrm{Na} \cdot \mathrm{kg}^{-1}$ d.m. (Jasiewicz \& Baran 2006). In turn, the content of macronutrients in the sediments of the Chechło Reservoir amounted to: $\mathrm{K}$ - from 0.10 to $2.56 \mathrm{~g}$; $\mathrm{Ca}$ - from 0.53 to $9.25 \mathrm{~g}$; $\mathrm{Na}$ - from 0.06 to $0.37 \mathrm{~g} ; \mathrm{Mg}$ - from 0.16 to $2.89 \mathrm{~g} \cdot \mathrm{kg}^{-1}$ d.m. (Zawisza et al. 2014). In the studies conducted by Niemiec (2007), the content of macro-elements in the sediments of the Rożnów Reservoir collected from the lagoon amounted to: $\mathrm{P}-0.532 \mathrm{~g} ; \mathrm{Mg}-$ 3,83 g; Ca -17.46 g; P - 0.973 g; K - 8.63 g.kg ${ }^{-1}$ d.m. The comparison shows that, on average, the tested sediments contain more phosphorus, calcium and less sodium, magnesium and potassium.

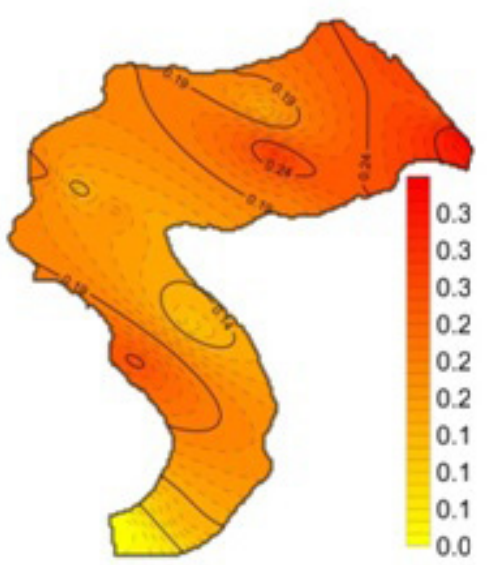

Na $g \cdot \mathrm{kg}^{-1}$

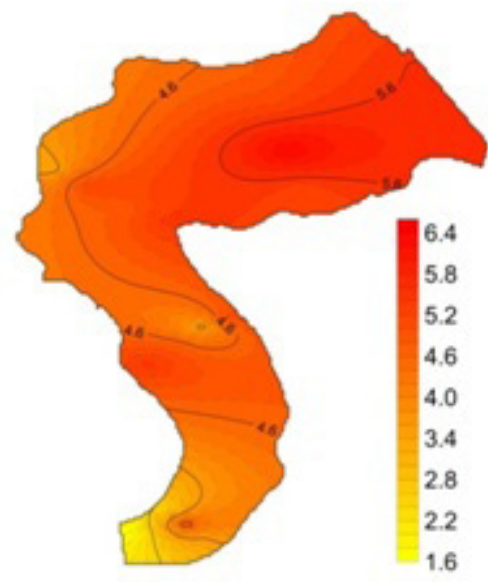

$\mathrm{Pg} \cdot \mathrm{kg}^{-1}$

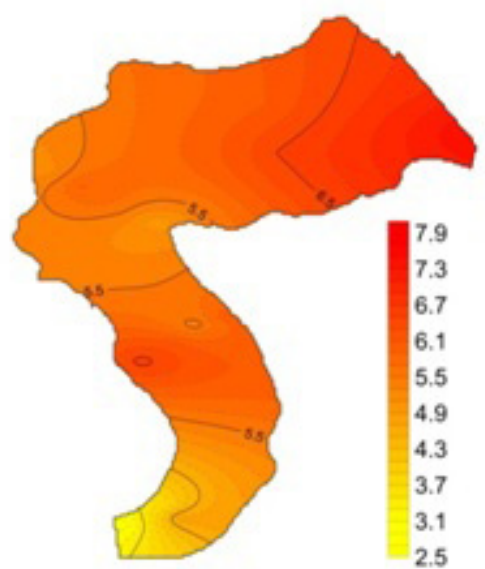

$\mathrm{Mg} g \cdot \mathrm{kg}^{-1}$

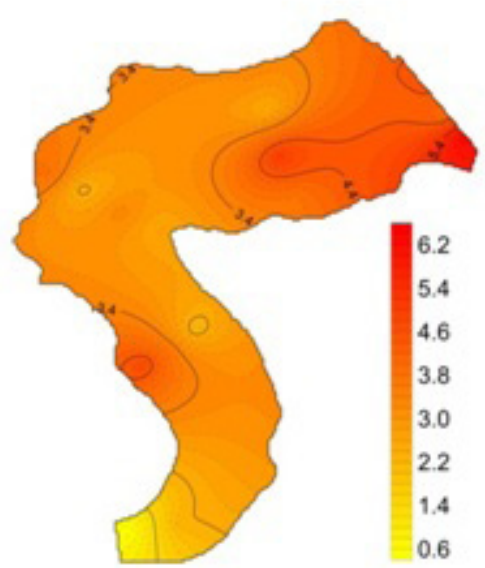

$\mathrm{Kg} \cdot \mathrm{kg}^{-1}$

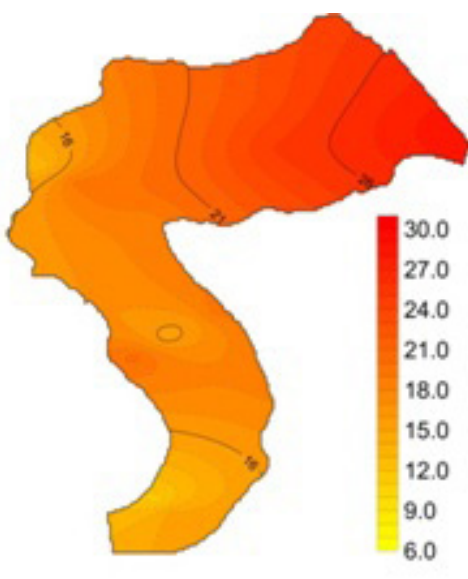

$\mathrm{Cag} \cdot \mathrm{kg}^{-1}$

Fig. 4. Spatial distribution of macro-elements in bottom sediments of the inlet zone of the Rożnów Reservoir 
Table 2

The total content of macronutrients in bottom sediments of the tested zone

\begin{tabular}{|c|c|c|c|c|c|c|c|}
\hline \multirow{2}{*}{$\begin{array}{c}\text { Pa- } \\
\text { rame- } \\
\text { ters }\end{array}$} & $\mathbf{N}$ & $S$ & $\mathrm{Na}$ & $\mathrm{Mg}$ & $\mathbf{K}$ & $\mathrm{Ca}$ & $\mathbf{P}$ \\
\hline & \multicolumn{7}{|c|}{$\left[\mathrm{g} \cdot \mathrm{kg}^{-1}\right.$ s.m. $]$} \\
\hline Mean & 1.14 & 0.32 & 0.18 & 5.77 & 3.28 & 20.16 & 4.75 \\
\hline SD & 0.39 & 0.24 & 0.07 & 1.33 & 1.34 & 6.57 & 1.14 \\
\hline Min. & 0.16 & 0.13 & 0.04 & 2.48 & 0.50 & 6.88 & 1.80 \\
\hline Max. & 1.77 & 0.88 & 0.33 & 7.59 & 6.27 & 29.88 & 6.42 \\
\hline CV\% & 34 & 74 & 39 & 23 & 41 & 33 & 24 \\
\hline
\end{tabular}

\section{DISCUSSION}

The bottom sediments of the Rożnów Reservoir were characterised by a neutral or an alkaline reaction, containing relatively large amounts of dusty and loam fractions as well as macro-elements, especially calcium. On the other hand, they were poor in organic carbon, nitrogen and sulphur. In conclusion, these sediments exhibit a high potential possibility of using them for environmental purposes. However, a thorough analysis of the environmental risks associated with heavy metals, PAHs, PCBs and their eco-toxicity is necessary to fully evaluate the use of sediments from this zone of the Rożnów Reservoir on land.

As shown in multiple studies, if the material extracted from the bottom of the silted reservoir does not pose a threat to the environment, an environmentally justified reason for using such sediment is to use it as a structure- and soil-forming material for soilless grounds and wastelands (Tarnawski et al. 2015, Baran et al. 2016). Bottom sediments, in particular those that are neutral or alkaline and contain a high content of dust and clay fractions, can be used to increase the productivity of light and acid soils (Baran et al. 2011, Tarnawski et al. 2015). The greatest disadvantage of light soils is their small sorption capacity relative to nutrients as well as their retention capacity relative to water. Even high doses of fertilisers on these soils do not produce positive results due to the rapid leaching of nutrients. The improvement of the quality of these soils and, consequently, their productivity and a reduction of negative impact on the environment will be possible thanks to the use of bottom sediments, for example from the Rożnów Reservoir. It is worth highlighting here that attempts to use bottom sediments of the Rożnów Reservoir for environmental purposes were the subject of research carried out by Niemiec (2007), Niemiec \& Wiśniowska-Kielian (2010a), Niemiec \& Wiśniowska-Kielian (2010b). In the cited studies, it was shown that the sediment dredged from the Rożnów Reservoir can be used as an additive to acidic and light soils on agricultural lands due to its favourable influence on the production of plant biomass and improvement of the soil properties. The authors also showed that this sediment may be recommended for the reclamation of contaminated soils due to the alkaline reaction favouring the immobilisation of potentially toxic heavy metals. In the studies conducted by Jasiewicz et al. (2011) and Baran et al. (2012) concerning the evaluation of the bottom sediments of the Besko and Zesławice reservoirs, similar to sediments of the Rożnów Reservoir in terms of their physical and chemical properties and their usefulness for agricultural purposes, a positive influence of bottom sediment on maize biomass production and its chemical composition was determined, with the highest maize yield obtained in the object with the lowest dose of bottom sediment amounting to $5 \%$. In the studies conducted by Niemiec (2007), it was also shown that a sediment dose of up to $10 \%$ was the most optimal. Larger doses of bottom sediment caused yield depression due to unfavourable air conditions formed in the substrate. The studies conducted by Baran et al. (2012) showed that the above-ground biomass of maize in objects with the addition of bottom sediments from the Besko Reservoir had deficient nitrogen, potassium and phosphorus content and optimum magnesium and calcium content. Deficiencies of nutrients, especially phosphorus, in plants regarding objects with the Rożnów Reservoir bottom sediments were also observed by Niemiec (2007). Low levels of macro-elements indicate the need for additional mineral fertilisation in the agricultural use of bottom sediments. In addition to the agricultural application of bottom sediments, some works concerning the use of bottom sediments in the reclamation of degraded areas are also included in the subject literature. Pelczar et al. (1998) reported that, in spite of the high content of fertilising substances, bottom sediments are not suitable for agricultural use due to the increased content 
of heavy metals. Such sediments should be used as a material for the reclamation of landfills containing hard coal mining and fly ash. The authors showed that the introduction of bottom sediment into mining waste changes their buffer properties, porosity, water retention capacity as well as increasing the content of organic substances and fertilising components, and increases the enzymatic activity of the soil. Bottom sediments from the Rożnów Reservoir can also be recommended for the reclamation of contaminated/chemically degraded soils due to a neutral/alkaline reaction and large sorption capacity conducive to the retention of pollutants, such as heavy metals. Studies on the use of bottom sediments from the Rożnów Reservoir for reclamation purposes were conducted by Komornicki et al. (2011). The authors showed that the tested sediment was characterised by good physical and chemical parameters, allowing it to be used in the reclamation of low-value soils, especially for the melioration of light soils.

\section{CONCLUSIONS}

1. The analysis of the physical and chemical properties of bottom sediments from the Rożnów Reservoir indicates the great potential possibility for using them for environmental purposes (agriculture, reclamation). These sediments can be recommended as a material used to increase the productivity of light soils by improving their physicochemical properties.

2. In order to fully evaluate the possibility of bottom sediment management, it is necessary to carry out an analysis of the ecological risk related to the content of potentially toxic substances (heavy metals, PAHs, PCBs) and to evaluate their eco-toxicity.

3. One of the main barriers to the environmental application of bottom sediments is the lack of appropriate legislation. At present, there is no legal basis for the recovery of bottom sediments derived from dredging reservoirs using the R10 "Land treatment resulting in benefit to agriculture or ecological improvement" method.

The studies were commissioned by the Regional Water Management Board in Krakow as part of the project entitled "Analysis of the investment program in the Dunajec catchment basin" and was financed by the Polish Ministry of Science and Higher Education.

\section{REFERENCES}

Al-Mur B., Quicksall A., Ansari A., 2017. Spatial and temporal distribution of heavy metals in coastal core sediments from the Red Sea, Saudi Arabia. Oceanologia, 59, 3, 262-270.

Baran A. \& Tarnawski M., 2012. Zawartość metali ciężkich $\mathrm{w}$ wyciągach wodnych sporządzonych $\mathrm{z}$ osadów dennych zbiornika rzeszowskiego. Proceedings of ECOpole, 6, 2, 2012, 671-675.

Baran A., Jasiewicz Cz. \& Tarnawski M., 2010. Effect of bottom deposit on trace element content in light soil. Ecological Chemistry and Engineering, 17, 12, 1553-1561.

Baran A., Tarnawski M. \& Kaczmarski M., 2011. Assessment of agricultural utilization of bottom sediment from the Besko Reservoir. Czasopismo Techniczne. Chemia 1-Ch, 8, 108, 3-11.

Baran A., Tarnawski M., Koniarz T. \& Jasiewicz C., 2016. Agricultural use of sediments from Narożniki reservoir yield and concentration of macronutrients and trace elements in the plant. Infrastruktura i Ekologia Terenów Wiejskich, IV/1, 1217-1228.

Becquart F., Bernard F., Abriak N.E. \& Zentar R., 2009. Monotonic aspects of the mechanical behaviour of bottom ash from municipal solid waste incineration and its potential use for road construction. Waste Management, 29, 1320-1329.

Canet R., Chaves C., Pomares R. \& Alibach R., 2003. Agricultural use of sediments from the Albufera Lake (eastern Spain). Agriculture, Ecosystems \& Environment, 95, 29-36.

Cieleszczuk T., Kusza G. \& Karwaczyńska U., 2011. Przyrodnicze wykorzystanie osadów dennych w świetle obowiązujących przepisów. Roczniki Ochrony Środowiska, 13, 1327-1338.

Działoszyńska-Wawrzkiewicz M., Moraczeska-Majkut M., Szymura E. \& Nocoń W., 2015. Ocena wpływu anrtopopresji w zlewni Kłodnicy na charakterystykę osadów dennych w Potoku Bileszowskim. Ochrona Środowiska, $37,2,5-54$.

Ebbs S., Talbott J. \& Sankaran R., 2006. Cultivation of garden vegetables in Peoria Pool sediments from the Illions River: A case study in trace element accumulation and dietary exposure. Environment International, 32, 766-744.

Fonseca R.M., Barriga F. \& Fyfe W.S., 1998. Reversing desertification by using same reservoir sediments as agriculture soils. Episodes, 21, 4, 218-224.

Fonseca R., Barriga F.J.A.S. \& Fyfe W. 2003. Dam Reservoir Sediments as Fertilizers and Artificial Soils. Case studies from Portugal and Brazil. [in:] Tazaki K. (ed.), Proceedings. Water and Soil Environments, Biological and Geological Perspectives. International Symposium of Kanazawa University, $21^{\text {st }}$ Century COE Program, Kanazawa, Japan, 55-62.

Jasiewicz C. \& Baran A., 2006. Charakterystyka osadów dennych dwóch zbiorników małej retencji wodnej. Journal of Elementology, 11, 3, 367-377. 
Jasiewicz C., Baran A. \& Tarnawski M., 2010. Effect of bottom sediment on content, bioaccumulation and translocation of heavy metals in maize biomass. Journal of Elementology, 15, 2, 281-291.

Jasiewicz C., Madeyski M., Tarnawski M. \& Baran A., 2011. The effect of bottom sediment supplement to soil on yield and chemical composition of maize. Ecological Chemistry and Engineering, 18, 11, 1505-1514.

Karanam P.V., Wani S.P, Sahrawat K.L. \& Jangawad L.S., 2008. Economic evaluation of sediment as a source of plant nutrients. Current Science, 95, 25, 1042-1050.

Komornicki T., Miczyński J. \& Oleksynowa K., 2011. Kształtowanie się właściwości fizycznych i chemicznych osadów dennych Zbiornika Rożnowskiego z możliwością zastosowania ich do rekultywacji. Acta Scientiarum Polonorum. Formatio Circumiectus, 10, 4, 31-50.

Koniarz T., Tarnawski M., Baran A. \& Florencka N., 2015. Mercury contamination of bottom sediments in water reservoirs of southern Poland. Geology, Geophysics \& Environment, 41, 2, 169-175.

Koś K. \& Zawisza E. 2012. Ocena przydatności osadów dennych Zbiornika Rzeszowskiego do budowy szczelin w składowiskach odpadów. Acta Scientiarum Polonorum. Formatio Circumiectus, 11, 4, 49-60.

Linczar M., Linczar S.E., Linczar P. \& Żmuda R. 2005. Właściwości osadów dennych cieku Mielnica. Acta Agrophisica, 5, 2, 345-355.

Maj K. \& Koszelnik P. 2016. Metody zagospodarowani osadów dennych. Czasopismo Inżynierii Lądowej, Środowiska i Architektury, 33, 63 (2/I/16), 157-169.

Mamindy-Pajany Y., Hamer B., Roméo M., Géret F., Galgani F., Durmisi E., Hurel C. \& Marmier N., 2011. The toxicity of composted sediments from Mediterranean ports evaluated by several bioassays. Chemosphere, 83, 3, 362-369.

Mattei P., Cincinelli A., Martellini T., Natalini R., Pascale E. \& Renella G., 2016. Reclamation of river dredged sediments polluted by PAHs by co-composting with green waste. Science of the Total Environment, 566-567, 567-574.

Meyers P.A., 1997. Organic geochemical proxies of paleoceanographic, paleolimnologic, and paleoclimatic processes. Organic Geochemistry, 27, 5/6, 213-250.

Niemiec M. \& Wiśniowska-Kielian B., 2010a. Effect of dredged bottom sediment addition to the substratum on the fodder value of plant material. Part 2. Quantitative ratios between macroelements. Ecological Chemistry and Engineering. A, 17, 8, 991-1000.

Niemiec M. \& Wiśniowska-Kielian B., 2010b. Effect of dredged bottom sediment addition to the substratum on the fodder value of plant material. Part 1. Macroelements content. Ecological Chemistry and Engineering, 17, 4-5, 461-472.

Niemiec M., 2007. Possibilities of agricultural management of the sediment dumped from the Rożnowski Reservoir. Akademia Rolnicza, Kraków [Ph.D. thesis]

Pelczar J., Loska K. \& Maleniu E. 1998. Wpływ nawożenia osadem dennym na aktywność enzymatyczną zwałowiska odpadów węgla kamiennego. Archiwum Ochrony Środowiska, 23, 3, 93-101.

Perrodin Y., Babut M., Bedell J.-P., Bray M., Clement B., Delolme C., Devaux A., Durrieu C., Garric J. \& Montuelle B.,
2006. Assessment of ecotoxicological risks related to depositing dredged materials from canals in northern France on soil. Environment International, 32, 804-814.

Piou S., Bataillard P., Laboudigue A., Ferard J-F. \& Masfaraud J-E., 2009. Changes in the geochemistry and ecotoxicity of a $\mathrm{Zn}$ and $\mathrm{Cd}$ contaminated dredged sediment over time after land disposal. Environmental Research, 109, 712-720.

Rozporządzenie, 2015. Rozporządzenie Ministra Środowiska $z$ dnia 11 maja 2015 r. w sprawie odzysku odpadów poza instalacjami i urządzeniami. Dz.U. 2015, poz. 796.

Sheehan C., Harrington J. \& Murphy J.D., 2010. A technical assessment of topsoil production from dredged material. Resources, Conservation and Recycling, 54, 1377-1385.

Siham K., Fabrice B., Edine AN. \& Patrick D., 2008. Marine dredged sediments as new materials resource for road construction. Waste Management, 28, 919-928.

Sobczyński T. \& Siepak J., 2001. Badania kumulacji związków biogennych i specjacji metali w osadach dennych jezior Wielkopolskiego Parku Narodowego. Zeszyty $\mathrm{Na}$ ukowe Politechniki Koszalińskiej, 20, 265-290.

Stephens S.R., Alloway B.J., Parker A., Carter J.E. \& Hudson M.E., 2001. Changes in the leachability of metals from dredged canal sediments during drying and oxidation. Environmental Pollution, 114, 407-413.

Szalińska E., 2011. Rola osadów dennych w ocenie jakości środowiska wód kontynentalnych. Monografia - Politechnika Krakowska im. Tadeusza Kościuszki. Inżynieria Środowiska, 396, Wydawnictwo PK, Kraków.

Tarnawski M., Baran A. \& Jasiewicz C., 2012 Assessment of physicochemical properties of the bottom sediments Chańcza reservoir. Proccedings of ECOpole, 6, 1, 305-311.

Tarnawski M., Baran A. \& Koniarz T., 2015. The effect of bottom sediment supplement on changes of soil properties and on the chemical composition of plants. Geology, Geophysics \& Environment, 41, 3, 285-292.

Terziyski D.I., Hadjinikolova L.D., Ivanova A.S. \& Kalchev R.K., 2014. Some chemical characteristics of sediments from carp fishponds treated with different fertilizers. Ecologia Balkanica, 5, 28-32.

Trojanowski J. \& Antonowicz J., 2005. Właściwości chemiczne osadów dennych jeziora Dołgie Wielkie. Stupskie Prace Biologiczne, 2, 123-133.

Walter K., Gunkel G. \& Gamboa N., 2012. An assessment of sediment reuse for sediment management of Gallito Ciego Reservoir, Peru. Lakes and Reservoir: Research and Management, 17, 301-314.

Wyrwicka A., Steffani S. \& Urbaniak M., 2014. The effect of PCB-contaminated sewage sludge and sediment on metabolism of cucumber plants (Cucumis sativus L.). Ecohydrology \& Hydrobiology, 14, 75-82.

Zawisza E., Michalec B., Gruchot A., Tarnawski M., Baran A., Cholewa M., Koś K. \& Koniarz T. (red.), 2014. Uwarunkowania techniczne rewitalizacji zbiornika wodnego Chechto w gminie Trzebinia. Wydawnictwo Uniwersytetu Rolniczego, Kraków.

Zentar R., Dubois V. \& Abriak N.E., 2008. Mechanical behaviour and environmental impacts of a test road built with marine dredged sediments. Resources, Conservation and Recycling, 52, 947-954. 